\title{
Can drinking tea prevent cancer?
}

\section{A controversy revisited}

\author{
Jan G. Hengstler $\cdot$ Rosemarie Marchan • \\ Hermann M. Bolt
}

Published online: 9 December 2008

(C) Springer-Verlag 2008

Tea remains one of the most consumed beverages worldwide and interestingly, several epidemiological studies suggest that the consumption of tea, in particular green tea, may prevent cancer. This has initiated a controversial debate about the potential anti-carcinogenic effects of tea and the possible mechanisms involved (Jankun et al. 1997; Yang 1997). In a widely cited correspondence, Jankun et al. identified the tea polyphenol epigallocateclin-3 gallate (EGCG), as an inhibitor of urokinase (uPA) (Jankun et al. 1997). EGCG was shown to block His 57 and Ser 195 of the uPA catalytic triad, thereby interfering with the ability of uPA to recognize its substrates (Jankun et al. 1997). However, the theory that tea polyphenols prevent cancer by inhibition of urokinase was almost immediately challenged (Yang 1997). One argument by Chung S. Yang was that the effective concentration of tea polyphenols needed to inhibit urokinase $(2-10 \mathrm{mM})$, suggested by Jankun et al. was at least three or four orders of magnitude higher than concentrations of EGCG normally expected in tissues (Yang 1997).

More than 10 years after the discussion of a role of urokinase inhibition as an anti-carcinogenic effect of tea polyphenols, much knowledge has been added to this field of research. Today, prevention of oxidative stress (Beyersmann and Hartwig 2008; Glahn et al. 2008; Arivarasu et al. 2008; Matés et al. 2008; Hengstler and Bolt 2008a, b; Sivalingam et al. 2008; Do Amaral et al. 2008; Abraham and Sugumar 2008), modulation of carcinogen metabolism (Strassburg et al. 2008; Pelkonen et al. 2008; Naraharisetti

J. G. Hengstler $(\varangle) \cdot$ R. Marchan · H. M. Bolt Leibniz-Institut für Arbeitsforschung an der TU Dortmund, Leibniz Research Centre for Working Environment and Human Factors (IfADo), Ardeystrasse 67, 44139 Dortmund, Germany e-mail: hengstler@ifado.de et al. 2008; Höhme et al. 2007; Hewitt et al. 2007; Hengstler et al. 2000) and prevention of DNA damage (Florl and Schulz 2008; Zhang et al. 2008; Hengstler and Bolt 2008a, b), mechanisms most frequently addressed in our journal, have also been suggested to contribute to the anti-carcinogenic effects of tea polyphenols. The editors are pleased that Chung S. Yang (University of New Jersey), Joshua D. Lamberg (The Pennsylvania State University) and Shengmin Sang (North Carolina Central University), some of the most recognized experts in the field of tea polyphenols, have accepted our invitation and contributed a comprehensive review about the anti-carcinogenic activities of tea (Yang et al. 2008).

\section{References}

Abraham P, Sugumar E (2008) Enhanced PON1 activity in the kidneys of cyclophosphamide treated rats may play a protective role as an antioxidant against cyclophosphamide induced oxidative stress. Arch Toxicol 82:237-238

Arivarasu NA, Fatima S, Mahmood R (2008) Oral administration of potassium dichromate inhibits brush border membrane enzymes and alters anti-oxidant status of rat intestine. Arch Toxicol 82(12):951-958

Beyersmann D, Hartwig A (2008) Carcinogenic metal compounds: recent insight into molecular and cellular mechanisms. Arch Toxicol 82:493-512

Do Amaral CL, Francescato HD, Coimbra TM, Costa RS, Darin JD, Antunes LM, Bianchi Mde L (2008) Resveratrol attenuates cisplatin-induced nephrotoxicity in rats. Arch Toxicol 82:363370

Florl AR, Schulz WA (2008) Chromosomal instability in bladder cancer. Arch Toxicol 82:173-182

Glahn F, Schmidt-Heck W, Zellmer S, Guthke R, Wiese J, Golka K, Hergenröder R, Degen GH, Lehmann T, Hermes M, Schormann W, Brulport M, Bauer A, Bedawy E, Gebhardt R, Hengstler JG, Foth H (2008) Cadmium, cobalt and lead cause stress response, cell cycle deregulation and increased steroid as well as xenobiotic 
metabolism in primary normal human bronchial epithelial cells which is coordinated by at least nine transcription factors. Arch Toxicol 82:513-524

Hengstler JG, Bolt HM (2008a) Loss of DNA damage checkpoint genes: switch from preferential induction of point mutations to chromosomal damage precedes the transition towards an aggressive cancer type. Arch Toxicol 82:341-342

Hengstler JG, Bolt HM (2008b) Oxidative stress: from modification of cell-cycle related events, secondary messenger function, dysregulation of small GTPases, protein kinases and phosphatases to redox-sensitive cancer models. Arch Toxicol 82:271-272

Hengstler JG, Utesch D, Steinberg P, Platt KL, Diener B, Ringel M, Swales N, Fischer T, Biefang K, Gerl M, Böttger T, Oesch F (2000) Cryopreserved primary hepatocytes as a constantly available in vitro model for the evaluation of human and animal drug metabolism and enzyme induction. Drug Metab Rev 32:81-118

Hewitt NJ, Lechón MJ, Houston JB, Hallifax D, Brown HS, Maurel P, Kenna JG, Gustavsson L, Lohmann C, Skonberg C, Guillouzo A, Tuschl G, Li AP, LeCluyse E, Groothuis GM, Hengstler JG (2007) Primary hepatocytes: current understanding of the regulation of metabolic enzymes and transporter proteins, and pharmaceutical practice for the use of hepatocytes in metabolism, enzyme induction, transporter, clearance, and hepatotoxicity studies. Drug Metab Rev 39:159-234

Höhme S, Hengstler JG, Brulport M, Schäfer M, Bauer A, Gebhardt R, Drasdo D (2007) Mathematical modelling of liver regeneration after intoxication with $\mathrm{CCl}(4)$. Chem Biol Interact 168:74-93
Jankun J, Selman SH, Swiercz R, Skrzypczak-Jankun E (1997) Why drinking green tea could prevent cancer. Nature 387:561

Matés JM, Segura JA, Alonso FJ, Márquez J (2008) Intracellular redox status and oxidative stress: implications for cell proliferation, apoptosis, and carcinogenesis. Arch Toxicol 82:273-299

Naraharisetti SB, Aggarwal M, Sarkar SN, Malik JK (2008) Concurrent subacute exposure to arsenic through drinking water and malathion via diet in male rats: effects on hepatic drug-metabolizing enzymes. Arch Toxicol 82:543-551

Pelkonen O, Turpeinen M, Hakkola J, Honkakoski P, Hukkanen J, Raunio H (2008) Inhibition and induction of human cytochrome P450 enzymes: current status. Arch Toxicol 82:667-715

Sivalingam N, Basivireddy J, Balasubramanian KA, Jacob M (2008) Curcumin attenuates indomethacin-induced oxidative stress and mitochondrial dysfunction. Arch Toxicol 82:471-481

Strassburg CP, Lankisch TO, Manns MP, Ehmer U (2008) Family 1 uridine-5' -diphosphate glucuronosyltransferases (UGT1A): from Gilbert's syndrome to genetic organization and variability. Arch Toxicol 82:415-433

Yang CS (1997) Inhibition of carcinogenesis by tea. Nature 389:134 135

Yang CS, Lambert JD, Sang S (2008) Antioxidative and anti-carcinogenic activities of tea polyphenols. Arch Toxicol. Accessed 12 Nov 2008 [Epub ahead of print]

Zhang QH, Wu CF, Duan L, Yang JY (2008) Protective effects of ginsenoside $\operatorname{Rg}(3)$ against cyclophosphamide-induced DNA damage and cell apoptosis in mice. Arch Toxicol 82:117-123 